Research Article

\title{
Optimization Studies on Recovery of Metals from Printed Circuit Board Waste
}

\author{
P. Sivakumar $(\mathbb{D}$, D. Prabhakaran, and M. Thirumarimurugan \\ Department of Chemical Engineering, Coimbatore Institute of Technology, Coimbatore 641 014, Tamil Nadu, India \\ Correspondence should be addressed to P. Sivakumar; chemsiva13@gmail.com
}

Received 20 June 2018; Accepted 18 September 2018; Published 1 November 2018

Academic Editor: Albrecht Messerschmidt

Copyright (C) 2018 P. Sivakumar et al. This is an open access article distributed under the Creative Commons Attribution License, which permits unrestricted use, distribution, and reproduction in any medium, provided the original work is properly cited.

\begin{abstract}
The aim of the study was to recover copper and lead metal from waste printed circuit boards (PCBs). The electrowinning method is found to be an effective recycling process to recover copper and lead metal from printed circuit board wastes. In order to simplify the process with affordable equipment, a simple ammonical leaching operation method was adopted. The selected PCBs were incinerated into fine ash powder at $500^{\circ} \mathrm{C}$ for 1 hour in the pyrolysis reactor. Then, the fine ash powder was subjected to acidleaching process to recover the metals with varying conditions like acid-base concentration, electrode combination, and leaching time. The relative electrolysis solution of $0.1 \mathrm{M}$ lead nitrate for lead and $0.1 \mathrm{M}$ copper sulphate for copper was used to extract metals from PCBs at room temperature. The amount of lead and copper extracted from the process was determined by an atomic absorption spectrophotometer, and results found were $73.29 \%$ and $82.17 \%$, respectively. Further, the optimum conditions for the recovery of metals were determined by using RSM software. The results showed that the percentage of lead and copper recovery were $78.25 \%$ and $89.1 \%$ should be $4 \mathrm{hrs} 10 \mathrm{~A} / \mathrm{dm}^{2}$.
\end{abstract}

\section{Introduction}

Recycling of e-waste is an important subject not only from the point of waste treatment but also from the recovery aspect of valuable materials [1-4]. Among the resources in e-waste, metals contribute more than $95 \%$ of the materials market value. Hence, the recovery of valuable metals is the inherent motive in e-waste disposal. In the past decades, many techniques for recovering valuable metals from e-waste have been developed such as gravity separation, magnetic separation, and electrostatic separation [5] synthesis of $\mathrm{CuCl}$ with e-waste, separation of PCBs with organic solvent method $[6,7]$, cyanide and noncyanide lixiviants leaching methods, ammonium persulfate leaching bioleaching methods [8-10], or a combination of these approaches. Among those methods, hydrometallurgical methods are more accurate, predictable, and controllable [11]. Therefore, hydrometallurgical techniques are most active in the research of valuable metal recovery from electronic scraps in the past two decades. However, traditional hydrometallurgical methods are acid dependent, time-consuming, and inefficient for simultaneous recovery of precious metals. Remarkably, a large amount of corrosive or toxic reagents, such as aqua regia, nitric acid, cyanide and halide, are consumed, producing large quantities of toxic and corrosive fumes or solution $[12,13]$. Therefore, it is necessary to seek a more environmental friendly method for the recovery of valuable metals from e-wastes. Hydrometallurgical methods are used in the upgrading and refining stages of the recycling chain [14-16]. In this research article, the recovery of lead and copper metals from e-waste is widely investigated. The PCBs were converted into fine ash powder and subjected to electrowinning process for the recovery of metals. The experimental results were determined by EDS and AAS, respectively. Furthermore, the experimental results are validated through RSM software at different parameters like acid-base concentration, electrode combination, and leaching time [17-22].

\section{Materials and Methods}

2.1. Materials. The computer PCBs were collected from various sources for the recovery of metals. The collected PCBs were crushed using roll crusher and powdered by a hammer mill. The crushed PCBs were incarnated through 
pyrolysis to avoid side reaction in the leaching process with the electrolyte solution. The optimum condition of the pyrolysis reactor was $500^{\circ} \mathrm{C}$ in atmospheric pressure for $1 \mathrm{~h}$ where the epoxy resins and polymers were volatized at the temperature less than $500^{\circ} \mathrm{C}$. The volatized contents were condensed and collected separately. The ferrous materials present in the obtained ash were separated by a magnetic separator.

2.2. Electrowinning Process. The fine ash powder was treated with aqua regia solution $\left(3: 1\right.$ ratio of $\mathrm{HCl}$ and $\left.\mathrm{HNO}_{3}\right)$ in the incineration chamber in order to avoid the liberation of toxic fumes. Then the precipitated salts obtained from the leaching was analyzed by EDS to determine the composition of metal present in the salts (Figure 1). The electrowinning setup consists of bath arrangement and amplifier. The bath having two slots for the anode and cathode fixing and the electrode is connected with amplifier, and the current density was varied through the amplifier (Figure 2).

2.3. Extraction Process of Lead. About $25 \mathrm{~g}$ of incinerated fine ash was added into the acid bath followed by the addition of ammonical electrolyte solution. The current density was set to 1 to $10\left(\mathrm{~A} / \mathrm{dm}^{2}\right)$. The solution was agitated at regular interval to get an effective electrodeposition:

$$
\mathrm{Pb}+4 \mathrm{HCl} \longrightarrow \mathrm{PbCl}_{4}+2 \mathrm{H}_{2}
$$

After the stipulated time of operation, pure lead was deposited on lead cathode. The deposited elements were scrapped and stored in an air tight container. The recovered lead quantitated from the EDS method. The spent acid left with mud filtered at $\mathrm{pH}$ 6-10 was stored in a glass container for further treatment.

2.4. Extraction Process of Copper. About $25 \mathrm{~g}$ of incinerated fine ash was added into the acid bath followed by the addition of ammonical electrolyte solution. The current density was set to 1 to $10\left(\mathrm{~A} / \mathrm{dm}^{2}\right)$. The solution was agitated at regular intervals to get an effective electrodeposition. After the stipulated time of operation, pure copper (cupric) was deposited on the cathode and impure copper (cuprous ion) were deposited on the anode. The deposited elements were scrapped and stored in an air tight container. The recovered copper quantitated from the EDS method. The spent acid left with mud (nonleached elements) was filtered ( $\mathrm{pH}-8.4)$ and were stored in a glass container for further treatment (Figure 3):

$$
2 \mathrm{Cu}^{2+}(\mathrm{aq})+2 \mathrm{H}_{2} \mathrm{O}(\mathrm{l}) \longrightarrow 2 \mathrm{Cu}(\mathrm{s})+4 \mathrm{H}^{+}(\mathrm{aq})+\mathrm{O}_{2}(\mathrm{~g})
$$

The spent solution collected from the electrodeposition was neutralized to 6.9 for the safe disposal as per the standard. Moreover, the presence of any metal in the spent solution was analyzed by Fourier-transform infrared spectroscopy. The results (Figure 4) show that the metallic traces were found to be absent which confirms that all the metals recovered from the ashes deposited on the electrode.

\section{Results and Discussion}

3.1. RSM for Lead. The response surface methodology (RSM) is a statistical modeling technique employed for multiple regression analysis using quantitative data obtained from designed experiments to solve multivariable equations (Table 1). The response surfaces can be visualized as threedimensional plots that exhibit the response as a function of two factors while keeping the other factors constant. In this above plot, the red zone corresponds to the extract percentage above $85 \%$, yellow zone shows 60 to $70 \%$, and the blue zone confirms below $40 \%$ extraction of lead (Figures 5 and 5(a)). The regression equation for the RSM data plots for the lead is

$$
\begin{aligned}
\text { Extract }= & 66.36+9.0175 * \mathrm{~A}+7.37375 * \mathrm{~B}+6.42375 * \mathrm{C} \\
& +1.235 * \mathrm{AB}+0.17 * \mathrm{AC}+(-7.1525 * \mathrm{BC}) \\
& +\left(-18.6187 * \mathrm{~A}^{2}\right)+\left(-1.67125 * \mathrm{~B}^{2}\right) \\
& +\left(-1.81625 * \mathrm{C}^{2}\right) .
\end{aligned}
$$

The model as a function of coded factor could be utilized to predict the response of each parameter within the given limit. Here, the maximum limit of process parameters (factors) is termed (coded) as +1 and minimum limit is terms (coded) as -1 . The modifed equation or coded equation is very much useful in order to find the comparative effect of the process parameters by relating the coefficient of factors. The final equation in terms of actual factors is

$$
\begin{aligned}
\text { Extract }= & -70.2665+5.06454 * \mathrm{CD}+0.201188 * \text { solvent } \\
& +25.6766 * \text { time }+0.000914815 * \mathrm{CD} * \text { solvent } \\
& +0.0125926 * \mathrm{CD} * \text { time } \\
& +(-0.0317889 * \text { solvent } * \text { time }) \\
& +\left(-0.229861 * \mathrm{CD}^{2}\right)+\left(-7.42778 e-05 * \text { solvent }^{2}\right) \\
& +\left(-0.807222 * \text { time }^{2}\right) .
\end{aligned}
$$

Equation (4) in terms of process parameters could be utilized to predict the response for the provided levels of each parameter (Table 2). In this equation, the original units of each parameters should be considered for each levels. In order to evaluate the comparative effect of each factor, the above equation should not be considered since the coefficients are balanced to embrace the units of each parameters. Also, the intercept does not fall at design space center.

3.2. Analysis of Variance (ANOVA). Analysis of variance is used to determine the significant effects of process variables on current efficiency (Table 3 ) along with the factor coding. The sum of squares is found to be Type III-partial derived from the ANOVA quadratic model. The model $F$ value of 4.43 implies the model is significant. A minimum value of $3.12 \%$ is possible for the $F$ value due to noise. $p$ values less 


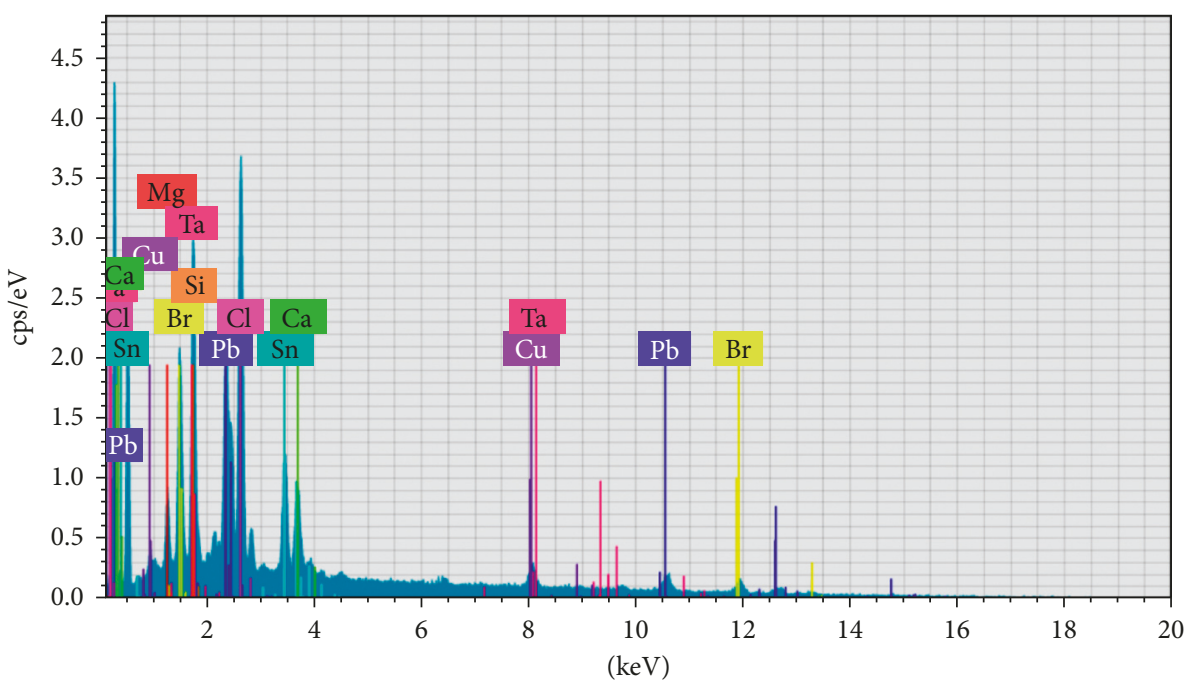

FIgURe 1: Initial analysis of raw materials.

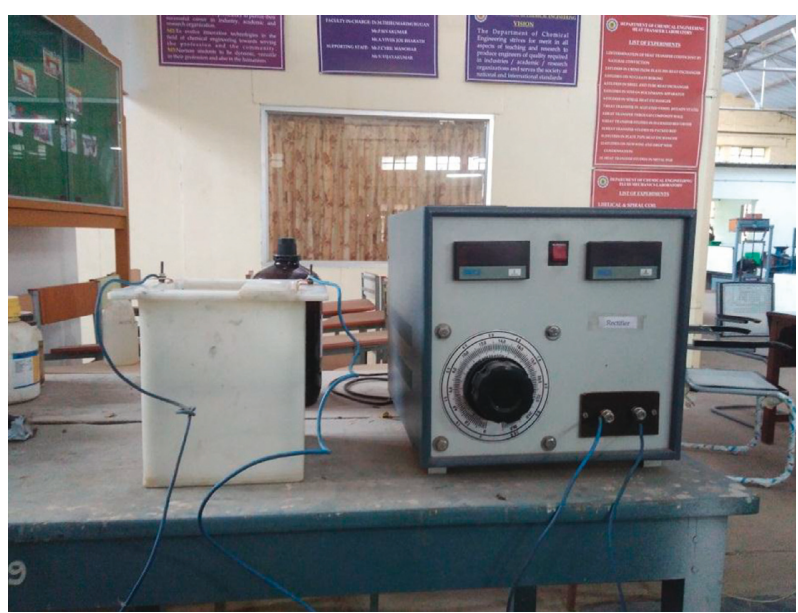

FIgURE 2: Experimental setup of electrowinning process.

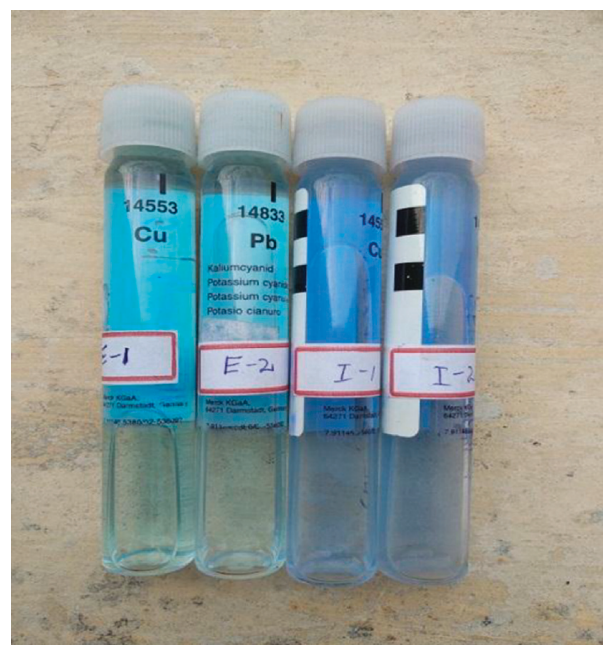

Figure 3: Bath solutions of copper and lead.

than 0.0500 indicate model terms are significant. In this case $\mathrm{A}, \mathrm{A}^{2}$ are significant model terms. Values greater than 0.1000 indicate the model terms are not significant. If there are many insignificant model terms (not counting those required to support hierarchy), model reduction may improve the model. The lack of fit $F$ value of 63.27 implies the lack of 

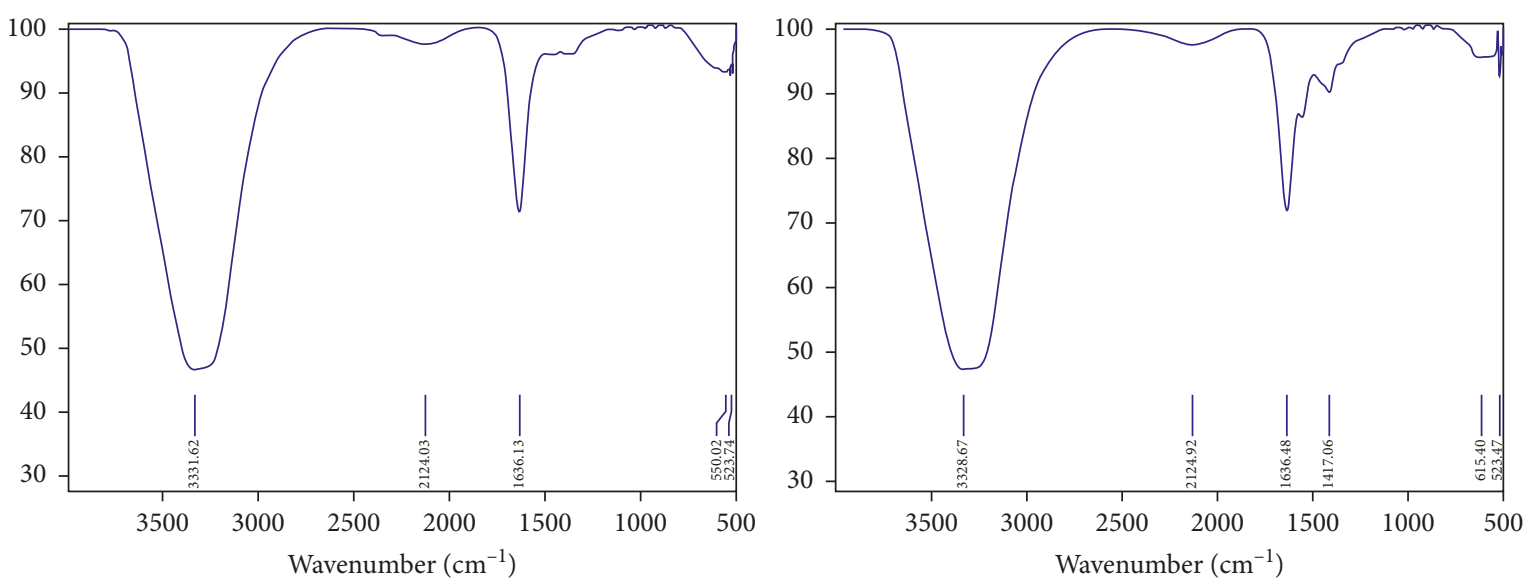

FIGURE 4: FTIR analysis of bath solution.

TABLE 1: RSM parameters for lead extraction.

\begin{tabular}{lcccc}
\hline Std & Run & $\begin{array}{c}\text { Factor } 1 \\
\text { A: CD } \\
\text { A/dm }\end{array}$ & $\begin{array}{c}\text { Factor 2 } \\
\text { B: solvent } \\
\text { ml }\end{array}$ & $\begin{array}{c}\text { Factor 3 } \\
\text { C: time } \\
\text { Hrs }\end{array}$ \\
\hline 1 & 8 & 1 & 400 & 2.5 \\
2 & 9 & 19 & 400 & 2.5 \\
3 & 17 & 1 & 700 & 2.5 \\
4 & 12 & 19 & 700 & 2.5 \\
5 & 1 & 1 & 550 & 1 \\
6 & 14 & 19 & 550 & 1 \\
7 & 6 & 1 & 550 & 4 \\
8 & 5 & 19 & 550 & 4 \\
9 & 4 & 10 & 400 & 1 \\
10 & 10 & 10 & 700 & 1 \\
11 & 7 & 10 & 400 & 4 \\
12 & 11 & 10 & 700 & 4 \\
13 & 2 & 10 & 550 & 2.5 \\
14 & 16 & 10 & 550 & 2.5 \\
15 & 13 & 10 & 550 & 2.5 \\
16 & 15 & 10 & 550 & 2.5 \\
17 & 3 & 10 & 550 & 2.5 \\
\hline
\end{tabular}

fit is significant. There is only a $0.08 \%$ chance that a lack of fit $F$ value could be large that could occur due to noise. The coefficient represents the expected change in response per unit change in the factor value, when all remaining factors were constant. The intercept in an orthogonal design is the overall average response of all the runs. The coefficients are adjustments around the average factor settings. When the factors are orthogonal, the variance inflation factors (VIFs) are 1; VIFs greater than 1 indicate multicolinearity; the higher the VIF, the more severe the correlation of factors. As a rough rule, VIFs less than 10 are tolerable. Hence, from the data obtained (Table 4), the VIF values of lead are found to be tolerable.

3.3. Model Terms. For a standard deviation of 1 , the power calculations are performed using response type "continuous," and parameters are $\Delta=2$ and $\sigma=1$. The power is evaluated over -1 to +1 coded factor space. From (Table 5 ), the standard errors should be similar to each other in a balanced design. The ideal VIF value should be 1, VIFs above 10 are cause for concern, and VIFs above 100 are cause for alarm, indicating coefficients are poorly estimated due to multicolinearity, where ideal $R \mathrm{i}^{2}$ is 0.0 . High $R \mathrm{i}^{2}$ means terms are correlated with each other, possibly leading to poor models. If the design has multilinear constraints, then multicolinearity will exist to a greater degree. This inflates the VIFs and the $R \mathrm{i}^{2}$, rendering these statistics would not perform well. Hence, FDS could be used. Power is an inappropriate tool to evaluate response surface designs. Use prediction-based metrics provided in this program via fraction of design space (FDS) statistics.

3.4. Fit Statistics. A negative predicted $R^{2}$ implies that the overall mean may be a better predictor of the response than the current model. In some cases, a higher order model may also predict better. Adeq. precision measures the signal to noise ratio. A ratio greater than 4 is desirable. The ratio of 5.915 indicates an adequate signal. This model can be used to navigate the design space. The optimization of current efficiency is shown in Figure 6. From the results, it is observed that $69 \%$ of lead extract is obtained at current density $=10 \mathrm{~A}$ $\mathrm{dm}^{-2}$, solvent ratio $=5: 2$, and the electrolysis time $=4$ hours (Figures 7 and 8). The significance of regression coefficients were analyzed using the $p$-test and $t$-test. The $p$ values are used to check the effect of interaction among the variables. A larger magnitude of $t$-value and a smaller magnitude of $p$ value are significant in the corresponding coefficient term. The coefficient of current efficiency and the corresponding $t$ and $p$ values are shown in Table 6 . Finally, the coefficients in the interaction terms for current density-electrolysis time is significant compared to current density-solvent ratio, and current density-electrolysis time.

3.5. RSM for Copper. The regression equation for the RSM data plots for the copper is in terms of coded factors form as follows: 


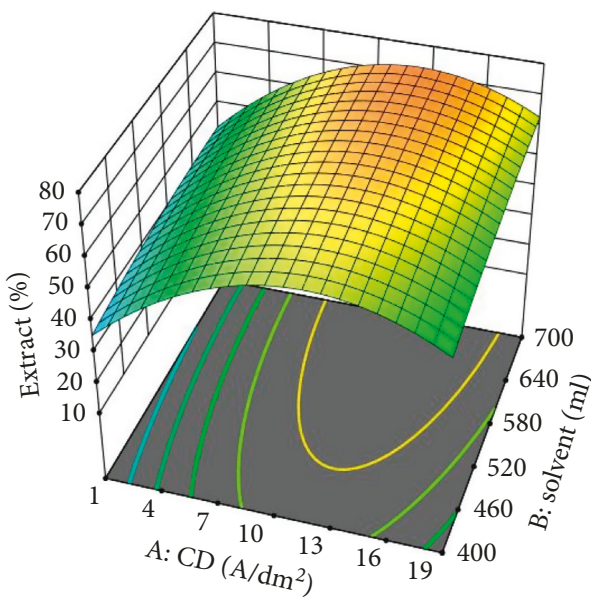

Extract (\%)

$28.85 \square 8.25$

$\mathrm{X} 1=\mathrm{A}: \mathrm{CD}$

$\mathrm{X} 2=\mathrm{B}$ : solvent

Actual factor

C: time $=3.1$

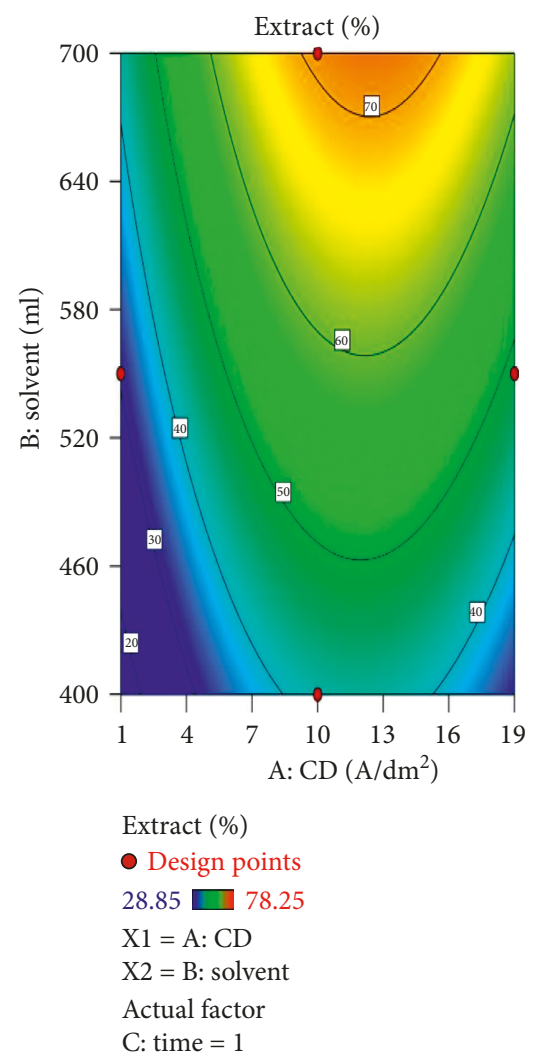

Figure 5: Contour plot for recovery of Lead.

TABle 2: Box-Behnken experimental design table for recovery of lead.

\begin{tabular}{lcccc}
\hline Std & Run & $\begin{array}{c}\text { Factor } 1 \\
\text { A: CD } \\
\text { A/dm }\end{array}$ & $\begin{array}{c}\text { Factor 2 } \\
\text { B: solvent } \\
\text { ml }\end{array}$ & $\begin{array}{c}\text { Factor 3 } \\
\text { C: time } \\
\text { Hrs }\end{array}$ \\
\hline 1 & 8 & 1 & 400 & 2.5 \\
2 & 9 & 19 & 400 & 2.5 \\
3 & 17 & 1 & 700 & 2.5 \\
4 & 12 & 19 & 700 & 2.5 \\
5 & 1 & 1 & 550 & 1 \\
6 & 14 & 19 & 550 & 1 \\
7 & 6 & 1 & 550 & 4 \\
8 & 5 & 19 & 550 & 4 \\
9 & 4 & 10 & 400 & 1 \\
10 & 10 & 10 & 700 & 1 \\
11 & 7 & 10 & 400 & 4 \\
12 & 11 & 10 & 700 & 4 \\
13 & 2 & 10 & 550 & 2.5 \\
14 & 16 & 10 & 550 & 2.5 \\
15 & 13 & 10 & 550 & 2.5 \\
16 & 15 & 10 & 550 & 2.5 \\
17 & 3 & 10 & 550 & 2.5 \\
\hline
\end{tabular}

$$
\begin{aligned}
\operatorname{Extract}(\mathrm{E})= & 48+24 * \mathrm{~A}+8.25 * \mathrm{~B}+15.5 * \mathrm{C}+0.5 * \mathrm{AB} \\
& +7.5 * \mathrm{AC}+2.5 * \mathrm{BC}+\left(-6.5 * \mathrm{~A}^{2}\right)+8 * \mathrm{~B}^{2} \\
& +1.5 * \mathrm{C}^{2}
\end{aligned}
$$

TABLE 3: ANOVA quadratic model for lead.

\begin{tabular}{lcccccc}
\hline Source & $\begin{array}{c}\text { Sum of } \\
\text { squares }\end{array}$ & DOF & $\begin{array}{c}\text { Mean } \\
\text { square }\end{array}$ & $F$ value & $p$ value & \\
\hline Model & 3152.45 & 9 & 350.27 & 4.43 & 0.0312 & Significant \\
A-CD & 650.52 & 1 & 650.52 & 8.23 & 0.0240 & \\
B-solvent & 434.98 & 1 & 434.98 & 5.51 & 0.0514 & \\
C-time & 330.12 & 1 & 330.12 & 4.18 & 0.0802 & \\
AB & 6.10 & 1 & 6.10 & 0.0772 & 0.7891 & \\
AC & 0.1156 & 1 & 0.1156 & 0.0015 & 0.9706 & \\
BC & 204.63 & 1 & 204.63 & 2.59 & 0.1516 & \\
$\mathrm{~A}^{2}$ & 1459.61 & 1 & 1459.61 & 18.47 & 0.0036 & \\
$\mathrm{~B}^{2}$ & 11.76 & 1 & 11.76 & 0.1489 & 0.7111 & \\
$\mathrm{C}^{2}$ & 13.89 & 1 & 13.89 & 0.1758 & 0.6876 & \\
Residual & 553.05 & 7 & 79.01 & & & \\
Lack of fit & 541.64 & 3 & 180.55 & 63.27 & 0.0008 & Significant \\
Pure & 11.41 & 4 & 2.85 & & & \\
error & & & & & & \\
Total & 3705.50 & 16 & & & & \\
\hline
\end{tabular}

The model (Equation 5) as a function of coded factor could be utilized to predict the response of each parameter within the given limit. Here, the maximum limit of process parameters (factors) is termed(coded) as +1 and minimum limit is termed (coded) as -1 . The modified equation or coded equation is very much useful in order to find the comparative effect of the process parameters by relating the coefficient of factors (Table 7).

The final equation in terms of actual factors is 
TABLE 4: Coefficients in terms of coded factors for lead.

\begin{tabular}{lcccccc}
\hline Factor & $\begin{array}{c}\text { Coefficient } \\
\text { estimate }\end{array}$ & DOF & $\begin{array}{c}\text { Standard } \\
\text { error }\end{array}$ & $\begin{array}{c}95 \% \\
\text { CI } \\
\text { low }\end{array}$ & $\begin{array}{c}\text { CI } \\
\text { high }\end{array}$ & VIF \\
\hline Intercept & 66.36 & 1 & 3.98 & 56.96 & 75.76 & \\
A-CD & 9.02 & 1 & 3.14 & 1.59 & 16.45 & 1.0000 \\
B-solvent & 7.37 & 1 & 3.14 & -0.0573 & 14.80 & 1.0000 \\
C-time & 6.42 & 1 & 3.14 & -1.01 & 13.85 & 1.0000 \\
AB & 1.24 & 1 & 4.44 & -9.27 & 11.74 & 1.0000 \\
AC & 0.1700 & 1 & 4.44 & -10.34 & 10.68 & 1.0000 \\
BC & -7.15 & 1 & 4.44 & -17.66 & 3.36 & 1.0000 \\
$\mathrm{~A}^{2}$ & -18.62 & 1 & 4.33 & -28.86 & -8.38 & 1.01 \\
$\mathrm{~B}^{2}$ & -1.67 & 1 & 4.33 & -11.91 & 8.57 & 1.01 \\
$\mathrm{C}^{2}$ & -1.82 & 1 & 4.33 & -12.06 & 8.43 & 1.01 \\
\hline
\end{tabular}

TABLE 5: Model terms in RSM for lead.

\begin{tabular}{lcccc}
\hline Term & Standard error & VIF & $R i^{2}$ & Power (\%) \\
\hline $\mathrm{A}$ & 0.3536 & 1 & 0.0000 & 68.1 \\
$\mathrm{~B}$ & 0.3536 & 1 & 0.0000 & 68.1 \\
$\mathrm{C}$ & 0.3536 & 1 & 0.0000 & 68.1 \\
$\mathrm{AB}$ & 0.5000 & 1 & 0.0000 & 40.8 \\
$\mathrm{AC}$ & 0.5000 & 1 & 0.0000 & 40.8 \\
$\mathrm{BC}$ & 0.5000 & 1 & 0.0000 & 40.8 \\
$\mathrm{~A}^{2}$ & 0.4873 & 1.00588 & 0.0058 & 93.8 \\
$\mathrm{~B}^{2}$ & 0.4873 & 1.00588 & 0.0058 & 93.8 \\
$\mathrm{C}^{2}$ & 0.4873 & 1.00588 & 0.0058 & 93.8 \\
\hline
\end{tabular}

Extract $=191.503+2.32716 * \mathrm{CD}+(-0.773056 *$ solvent $)$

$$
\begin{aligned}
& +(-11.3333 * \text { time })+0.000555556 * \mathrm{CD} * \text { solvent } \\
& +0.833333 * \mathrm{CD} * \text { time }+0.025 * \text { solvent } * \text { time } \\
& +\left(-0.0802469 * \mathrm{CD}^{2}\right)+0.0008 * \text { solvent }^{2} \\
& +1.5 * \text { time }^{2}
\end{aligned}
$$

Equation (5) in terms of process parameters could be utilized to predict the response for the provided levels of each parameter. In this equation, the original units of each parameters should be considered for each levels. In order to evaluate the comparative effect of each factor, the above equation should not be considered since the coefficients are balanced to embrace the units of each parameters. Also, the intercept does not falls at design space center (Table 8). In this contour plot, the red zone indicates extract percentages above $85 \%$. And yellow and blue zones indicate 60 to $70 \%$ and below $40 \%$ extraction of copper (Figures 9 and $9(\mathrm{a})$ ).

3.6. Analysis of Variance (ANOVA). Analysis of variance is used to determine the significant effects of process variables on current efficiency along with the factor coding. The sum of squares is found to be Type III-partial derived from the ANOVA quadratic model. The model $F$ value of 155.08 in the Table 9 implies the model is significant. A minimum value of $0.01 \%$ is possible for the $F$ value due to noise. $P$ values less than 0.0500 indicate model terms are significant.

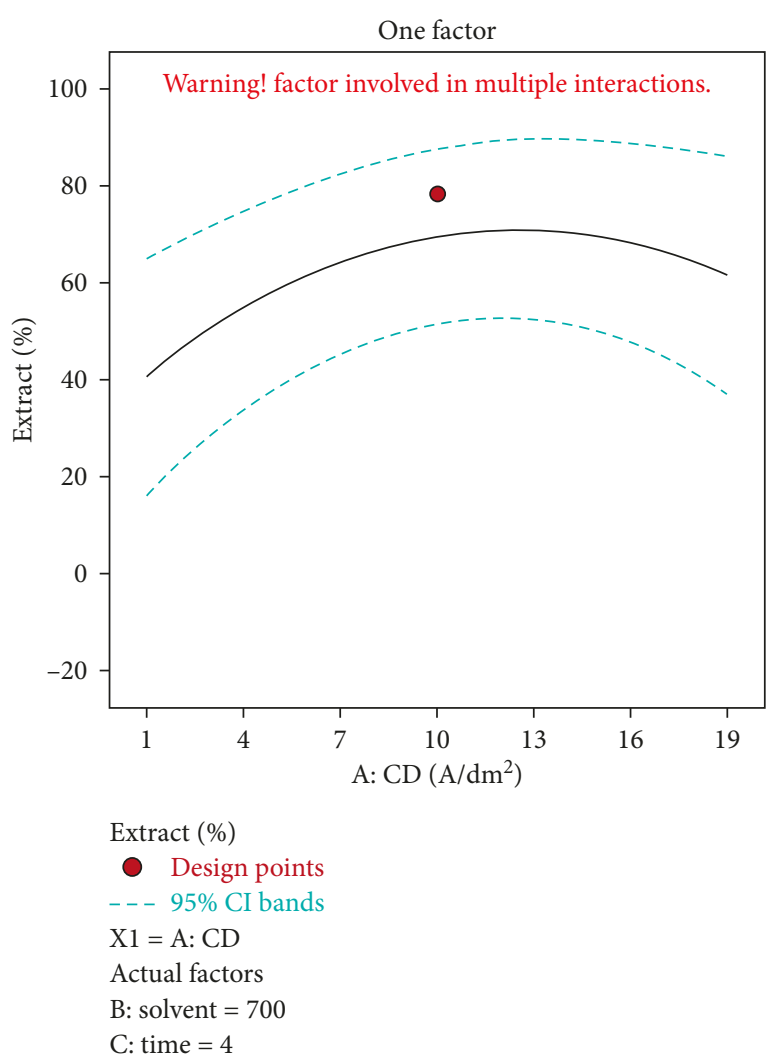

Figure 6: Current density vs extract \% for lead.

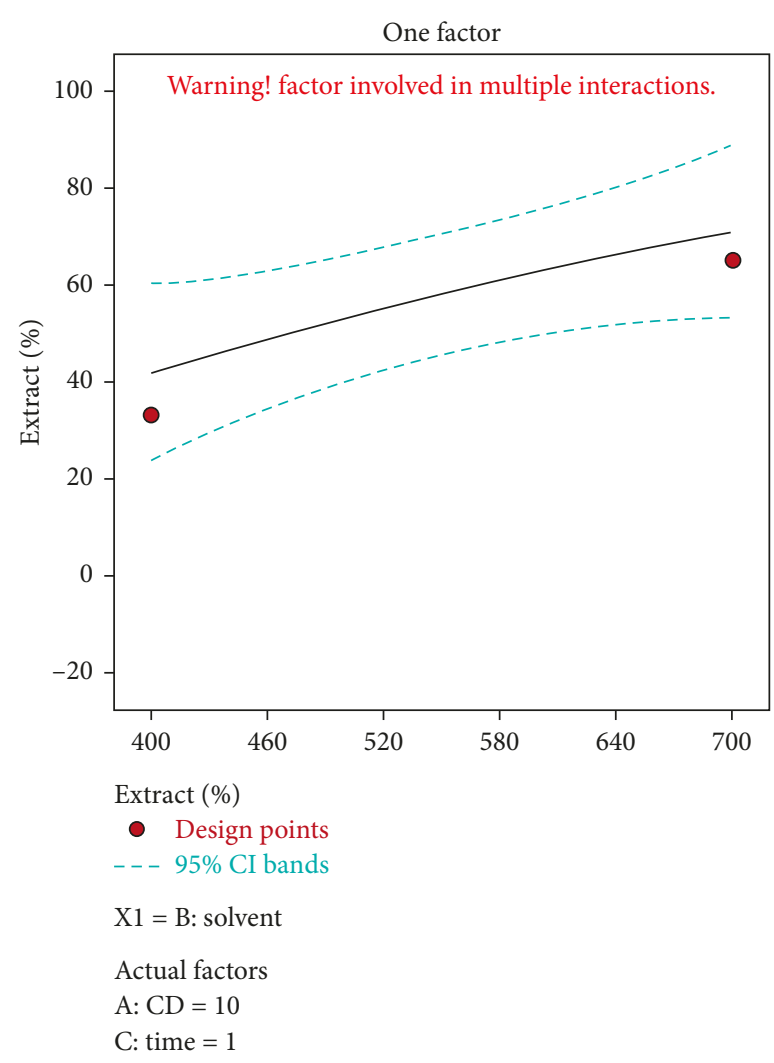

Figure 7: Solvent vs extract \% for lead. 


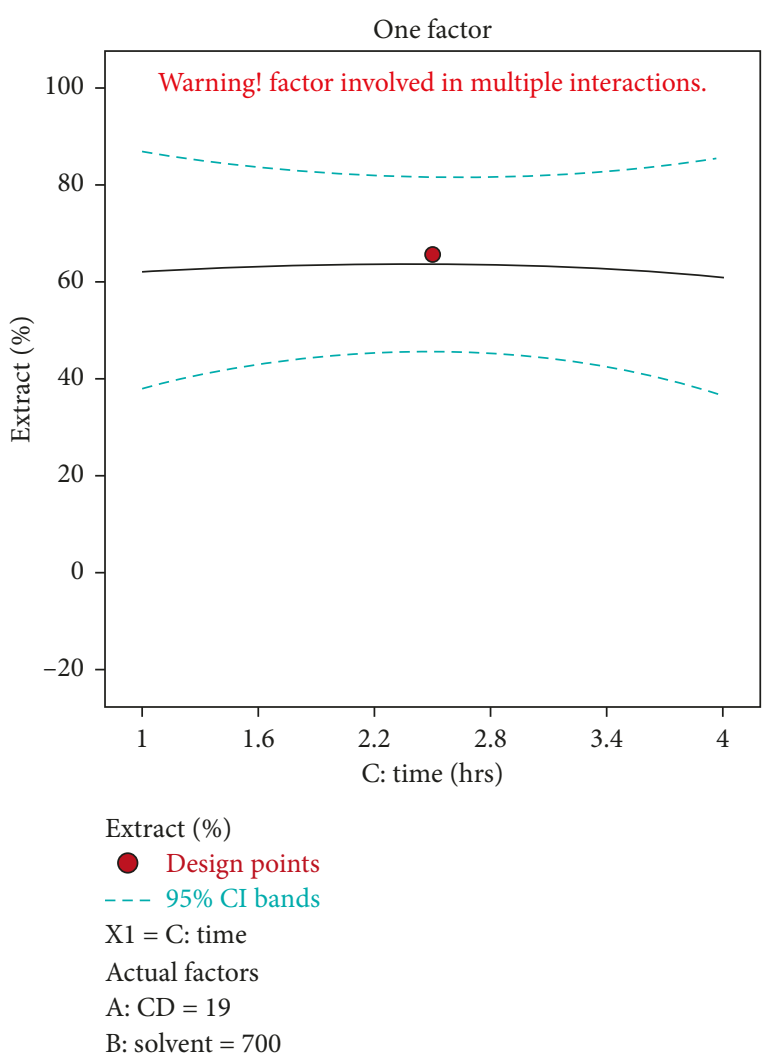

Figure 8: Time vs extract \% for lead.

TABLE 6: Fit statistics.

\begin{tabular}{lc}
\hline Std. dev. & \\
Mean & 8.89 \\
CV $(\%)$ & 55.96 \\
$R^{2}$ & 15.88 \\
Adjusted $R^{2}$ & 0.8507 \\
Predicted $R^{2}$ & 0.6589 \\
Adeq. precision & -1.3436 \\
\hline
\end{tabular}

TABLE 7: RSM parameters for copper extraction.

\begin{tabular}{lcccc}
\hline Std & Run & $\begin{array}{c}\text { Factor } 1 \\
\text { A: CD } \\
\text { A/dm }\end{array}$ & $\begin{array}{c}\text { Factor } 2 \\
\text { B: solvent } \\
\text { ml }\end{array}$ & $\begin{array}{c}\text { Factor 3 } \\
\text { C: time } \\
\text { Hrs }\end{array}$ \\
\hline 1 & 12 & 1 & 400 & 2 \\
2 & 14 & 19 & 400 & 2 \\
3 & 2 & 1 & 600 & 2 \\
4 & 4 & 19 & 600 & 2 \\
5 & 18 & 1 & 500 & 1 \\
6 & 13 & 19 & 500 & 1 \\
7 & 16 & 1 & 500 & 3 \\
8 & 11 & 19 & 500 & 3 \\
9 & 8 & 10 & 400 & 1 \\
10 & 1 & 10 & 600 & 1 \\
11 & 6 & 10 & 400 & 3 \\
12 & 7 & 10 & 600 & 3 \\
13 & 5 & 10 & 500 & 2 \\
14 & 9 & 10 & 500 & 2 \\
15 & 17 & 10 & 500 & 2 \\
16 & 3 & 10 & 500 & 2 \\
17 & 15 & 10 & 500 & 2 \\
\hline
\end{tabular}

TABLE 8: Box-Behnken experimental design table for recovery of copper.

\begin{tabular}{lcccc}
\hline Std & Run & $\begin{array}{c}\text { Factor } 1 \\
\text { A: CD } \\
\text { A/dm }\end{array}$ & $\begin{array}{c}\text { Factor 2 } \\
\text { B: solvent } \\
\text { ml }\end{array}$ & $\begin{array}{c}\text { Factor 3 } \\
\text { C: time } \\
\text { Hrs }\end{array}$ \\
\hline 1 & 12 & 1 & 400 & 2 \\
2 & 14 & 19 & 400 & 2 \\
3 & 2 & 1 & 600 & 2 \\
4 & 4 & 19 & 600 & 2 \\
5 & 18 & 1 & 500 & 1 \\
6 & 13 & 19 & 500 & 1 \\
7 & 16 & 1 & 500 & 3 \\
8 & 11 & 19 & 500 & 3 \\
9 & 8 & 10 & 400 & 1 \\
10 & 1 & 10 & 600 & 1 \\
11 & 6 & 10 & 400 & 3 \\
12 & 7 & 10 & 600 & 3 \\
13 & 5 & 10 & 500 & 2 \\
14 & 9 & 10 & 500 & 2 \\
15 & 17 & 10 & 500 & 2 \\
16 & 3 & 10 & 500 & 2 \\
17 & 15 & 10 & 500 & 2 \\
18 & 10 & 10 & 500 & 2 \\
\hline
\end{tabular}

In this case, $\mathrm{A}, \mathrm{B}, \mathrm{C}, \mathrm{AC}, \mathrm{A}^{2}$, and $\mathrm{B}^{2}$ are significant model terms. Values greater than 0.1000 indicate the model terms are not significant. If there are many insignificant model terms (not counting those required to support hierarchy), model reduction may improve the model. The lack of fit $F$ value is nil that implies the lack of fit is significant. The coefficient represents the expected change in response per unit change in factor value, when all remaining factors were constant. The intercept in an orthogonal design is the overall average response of all the runs. The coefficients are adjustments around the average factor settings. When the factors are orthogonal, the VIFs are 1; VIFs greater than 1 indicate multicolinearity; the higher the VIF, the more severe the correlation of factors. As a rough rule, VIFs less than 10 are tolerable. Hence, from the data obtained (Table 10), the VIF Values of lead are found to be tolerable.

3.7. Model Terms. For a standard deviation of 1 the power calculations are performed using response type "continuous," and the parameters are $\Delta=2$ and $\sigma=1$. The power is evaluated over -1 to +1 coded factor space (Table 11). The standard errors should be similar to each other in a balanced design. The ideal VIF value should be 1 , VIFs above 10 are cause for concern and VIFs above 100 are cause for alarm, indicating coefficients are poorly estimated due to multicolinearity, where ideal $R \mathrm{i}^{2}$ is 0.0 . High $R \mathrm{i}^{2}$ means terms are correlated with each other, possibly leading to poor models. If the design has multilinear constraints, then multicolinearity will exist to a greater degree. This inflates the VIFs and the $R \mathrm{i}^{2}$, rendering these statistics would not perform well. Hence, FDS could be used. Power is an inappropriate tool to evaluate response surface designs. Use prediction-based metrics provided in this program via fraction of design space (FDS) statistics. 

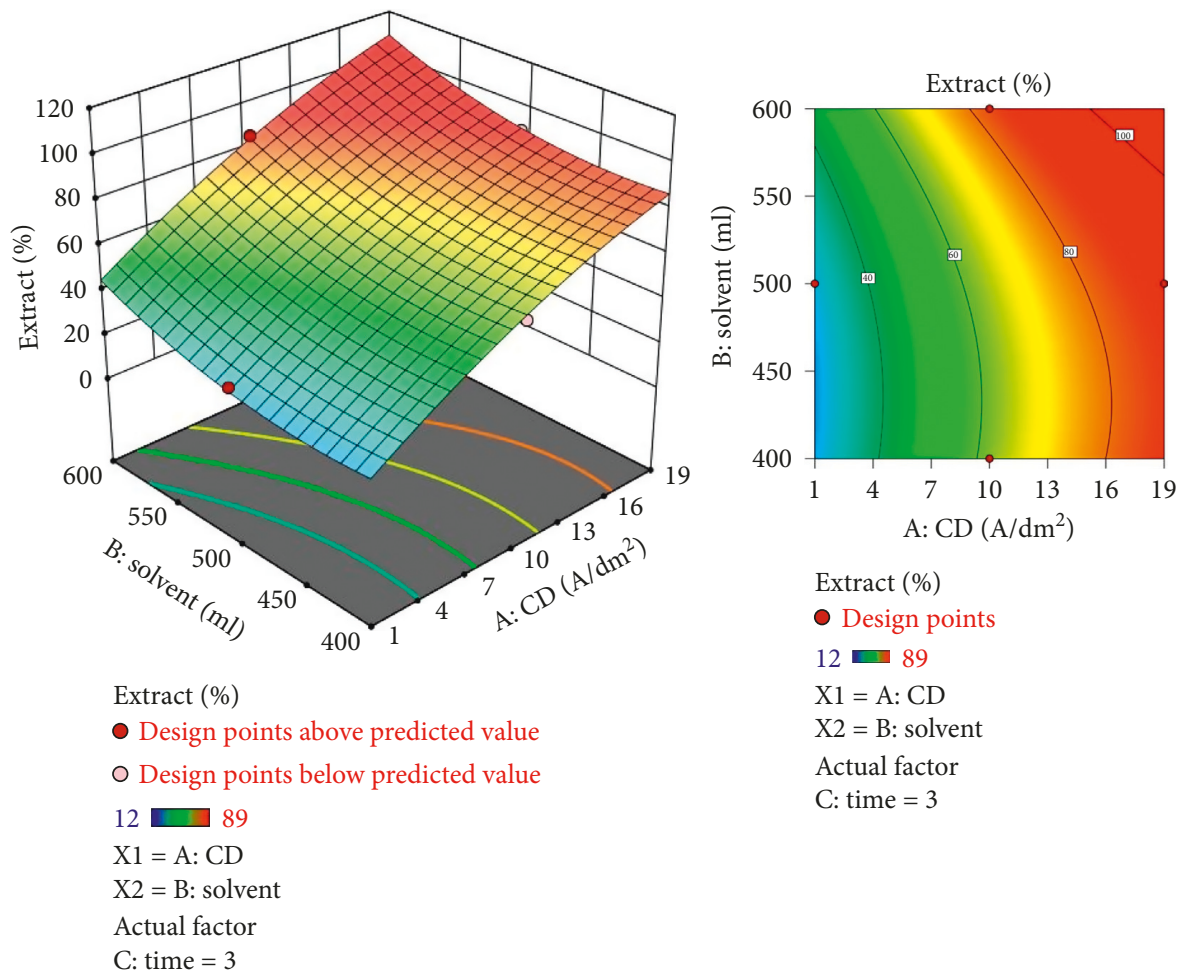

Extract (\%)

- Design points

$12=89$

$\mathrm{X} 1=\mathrm{A}: \mathrm{CD}$

$\mathrm{X} 2$ = B: solvent

Actual factor

C: time $=3$

FIgURE 9: Contour plot for recovery of copper.

TABle 9: ANOVA quadratic model for copper.

\begin{tabular}{|c|c|c|c|c|c|c|}
\hline Source & $\begin{array}{l}\text { Sum of } \\
\text { squares }\end{array}$ & DOF & $\begin{array}{l}\text { Mean } \\
\text { square }\end{array}$ & $\begin{array}{c}F \\
\text { value }\end{array}$ & $p$ value & \\
\hline Model & 7763.50 & 9 & 862.61 & 155.08 & $<0.0001$ & Significant \\
\hline $\mathrm{A}-\mathrm{CD}$ & 4608.00 & 1 & 4608.00 & 828.40 & $<0.0001$ & \\
\hline B-solvent & 544.50 & 1 & 544.50 & 97.89 & $<0.0001$ & \\
\hline C-time & 1922.00 & 1 & 1922.00 & 345.53 & $<0.0001$ & \\
\hline $\mathrm{AB}$ & 1.0000 & 1 & 1.0000 & 0.1798 & 0.6827 & \\
\hline $\mathrm{AC}$ & 225.00 & 1 & 225.00 & 40.45 & 0.0002 & \\
\hline BC & 25.00 & 1 & 25.00 & 4.49 & 0.0668 & \\
\hline$A^{2}$ & 184.36 & 1 & 184.36 & 33.14 & 0.0004 & \\
\hline $\mathrm{B}^{2}$ & 279.27 & 1 & 279.27 & 50.21 & 0.0001 & \\
\hline$C^{2}$ & 9.82 & 1 & 9.82 & 1.77 & 0.2206 & \\
\hline Residual & 44.50 & 8 & 5.56 & & & \\
\hline $\begin{array}{l}\text { Lack of } \\
\text { fit }\end{array}$ & 44.50 & 3 & 14.83 & & & \\
\hline $\begin{array}{l}\text { Pure } \\
\text { error }\end{array}$ & 0.0000 & 5 & 0.0000 & & & \\
\hline Total & 7808.00 & 17 & & & & \\
\hline
\end{tabular}

3.8. Fit Statistics. A predicted $R^{2}$ implies that the overall mean may be a better predictor of the response than the current model. In some cases, a higher order model may also predict better. Adeq. precision measures the signal to noise ratio. A ratio greater than 4 is desirable. A ratio of 44.9 indicates an adequate signal. This model can be used to navigate the design space. The optimization of current efficiency is shown in Figure 10. The optimum extraction of $69 \% \mathrm{Cu}$ is obtained at current density $=19 \mathrm{~A} \mathrm{dm}^{-2}$, solvent ratio $=5: 2$, and electrolysis time $=4$ hour (Figures 11 and 12). The significance of regression coefficients was analyzed using the $p$-test and $t$-test. The $p$ values are used to check the
TABLE 10: Coefficients in terms of coded factors for copper.

\begin{tabular}{lcccccc}
\hline Factor & $\begin{array}{c}\text { Coefficient } \\
\text { estimate }\end{array}$ & DOF & $\begin{array}{c}\text { Standard } \\
\text { error }\end{array}$ & $\begin{array}{c}95 \% \mathrm{CI} \\
\text { low }\end{array}$ & $\begin{array}{c}\text { CI } \\
\text { high }\end{array}$ & VIF \\
\hline Intercept & 48.00 & 1 & 0.9629 & 45.78 & 50.22 & \\
A-CD & 24.00 & 1 & 0.8339 & 22.08 & 25.92 & 1.0000 \\
B- & 8.25 & 1 & 0.8339 & 6.33 & 10.17 & 1.0000 \\
solvent & & & & & & \\
C-time & 15.50 & 1 & 0.8339 & 13.58 & 17.42 & 1.0000 \\
AB & 0.5000 & 1 & 1.18 & -2.22 & 3.22 & 1.0000 \\
AC & 7.50 & 1 & 1.18 & 4.78 & 10.22 & 1.0000 \\
BC & 2.50 & 1 & 1.18 & -0.2193 & 5.22 & 1.0000 \\
$\mathrm{~A}^{2}$ & -6.50 & 1 & 1.13 & -9.10 & -3.90 & 1.02 \\
$\mathrm{~B}^{2}$ & 8.00 & 1 & 1.13 & 5.40 & 10.60 & 1.02 \\
$\mathrm{C}^{2}$ & 1.50 & 1 & 1.13 & -1.10 & 4.10 & 1.02 \\
\hline
\end{tabular}

TABLE 11: Model terms in RSM for copper.

\begin{tabular}{lcccc}
\hline Term & Standard error & VIF & $R^{2}$ & Power $(\%)$ \\
\hline $\mathrm{A}$ & 0.3536 & 1 & 0.0000 & 69.8 \\
$\mathrm{~B}$ & 0.3536 & 1 & 0.0000 & 69.8 \\
$\mathrm{C}$ & 0.3536 & 1 & 0.0000 & 69.8 \\
$\mathrm{AB}$ & 0.5000 & 1 & 0.0000 & 42.1 \\
$\mathrm{AC}$ & 0.5000 & 1 & 0.0000 & 42.1 \\
$\mathrm{BC}$ & 0.5000 & 1 & 0.0000 & 42.1 \\
$\mathrm{~A}^{2}$ & 0.4787 & 1.01852 & 0.0182 & 95.4 \\
$\mathrm{~B}^{2}$ & 0.4787 & 1.01852 & 0.0182 & 95.4 \\
$\mathrm{C}^{2}$ & 0.4787 & 1.01852 & 0.0182 & 95.4 \\
\hline
\end{tabular}

effect of interaction among the variables. A larger magnitude of $t$-value and a smaller magnitude of $p$ value are significant in the corresponding coefficient term. The coefficient of 

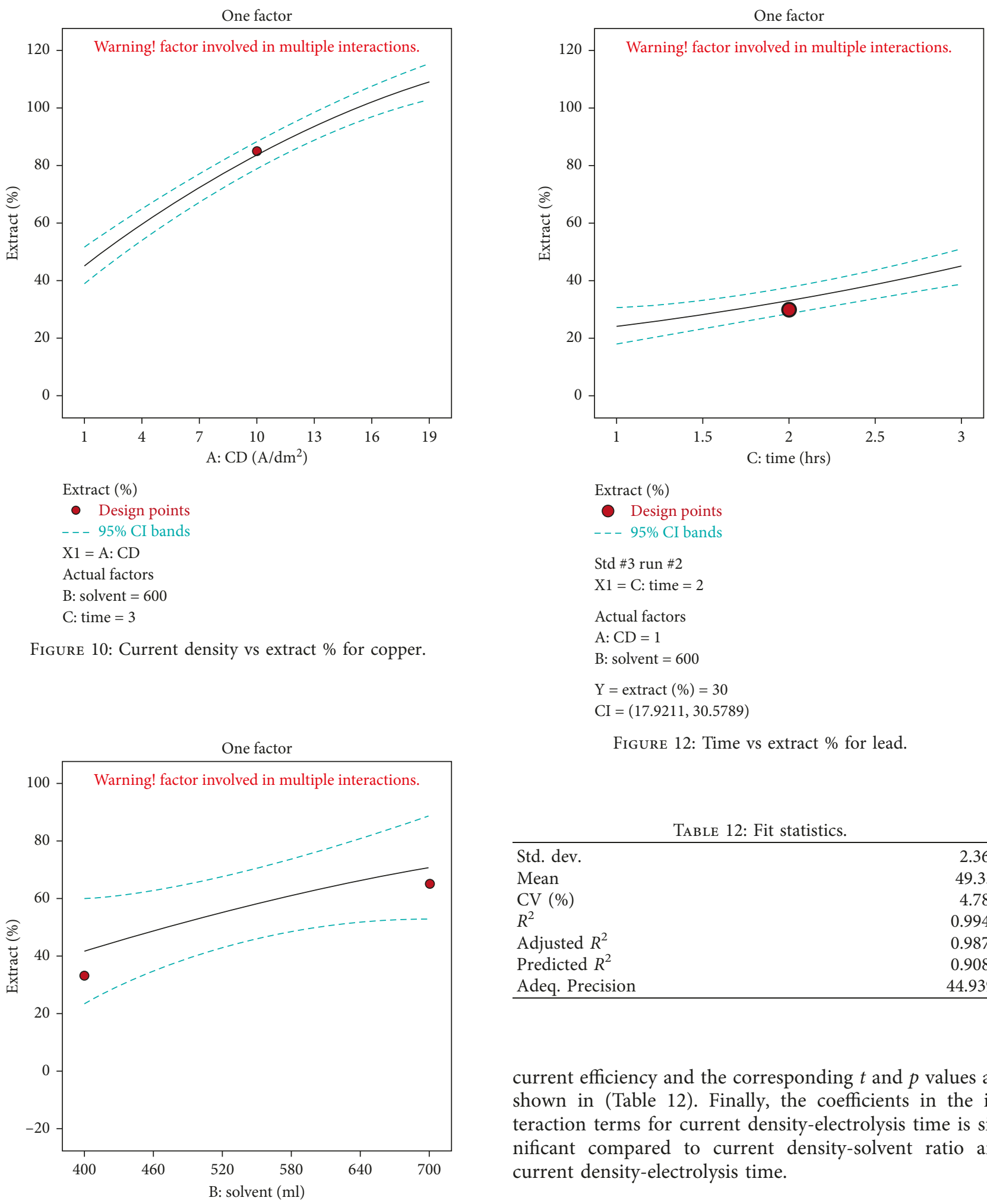

Figure 12: Time vs extract \% for lead.

Extract (\%)

- Design points

- - $95 \%$ CI bands

$\mathrm{X} 1=\mathrm{A}: \mathrm{CD}$

Actual factors

B: solvent $=600$

C: time $=3$

Figure 10: Current density vs extract \% for copper.

TABle 12: Fit statistics.

\begin{tabular}{lc}
\hline Std. dev. & 2.36 \\
Mean & 49.33 \\
CV $(\%)$ & 4.78 \\
$R^{2}$ & 0.9943 \\
Adjusted $R^{2}$ & 0.9879 \\
Predicted $R^{2}$ & 0.9088 \\
Adeq. Precision & 44.9395 \\
\hline
\end{tabular}

current efficiency and the corresponding $t$ and $p$ values are shown in (Table 12). Finally, the coefficients in the interaction terms for current density-electrolysis time is significant compared to current density-solvent ratio and current density-electrolysis time.

\section{Conclusion}

- Design points

- - - 95\% CI bands

$\mathrm{X} 1$ = B: solvent

Actual factors

A: $\mathrm{CD}=10$

C: time $=1$

FIgURE 11: Solvent vs extract \% for lead.

The ammonia-lead nitrate and ammonia-copper sulphate system have been employed as a leaching agent for recovery of lead and copper from scraped printed circuit board wastes. A two-stage leaching was employed, wherein the first stage consisted of leaching the scrap board with $0.1 \mathrm{M} \mathrm{Pb}$ $\left(\mathrm{NO}_{3}\right)_{2}$ and $0.1 \mathrm{M} \mathrm{CuSO}_{4}$ which results in the selective 
dissolution of lead and copper leaching rate, and other metals was found in lower amounts, respectively. The undissolved residue portion from the leaching stage containing nickel, tin, and silica were leached out in respective treatments. The current efficiency was found to increase with current density and concentration ratio with the contact time in acid bath. Hence, $73.29 \%$ lead and $82.17 \%$ copper have been successfully recovered from the electrolysis process. And, also by RSM Software prediction, the recovery of lead and copper are as $78.25 \%$ and $89.1 \%$, respectively. In addition to the quadratic model equation, ANOVA, model terms, and fit statistics were also tested for the experimental conditions.

\section{Data Availability}

All the data used to support the findings of this study are included within the article.

\section{Conflicts of Interest}

The authors declare that they have no conflicts of interest.

\section{Acknowledgments}

The authors convey sincere thanks to the Management and Principal of Coimbatore Institute of Technology, Coimbatore-641014, for sponsoring the project through the TEQIP-II fund.

\section{References}

[1] A. Mecucci and K. Scott, "Leaching and electrochemical recovery of copper, lead and tin from scrap printed circuit boards," Journal of Chemical Technology and Biotechnology, vol. 77, no. 4, pp. 449-457, 2002.

[2] B.-S. Kim, J.-C. Lee, S.-P. Seo, Y.-K. Park, and H. Y. Sohn, “A process for extracting precious metals from spent printed circuit boards and automobile catalysts," Journal of Minerals, Metals and Materials, vol. 56, no. 12, pp. 55-58, 2004.

[3] J. Cui and L. Zhang, "Metallurgical recovery of metals from electronic waste: a review," Journal of Hazardous materials, vol. 158, no. 2-3, pp. 228-256, 2008.

[4] F.-R. Xiu and F.-S. Zhang, "Recovery of copper and lead from waste printed circuit boards by supercritical water oxidation combined with electrokinetic process," Journal of Hazardous materials, vol. 165, no. 1-3, pp. 1002-1007, 2009.

[5] J. Guo and Z. Xu, "Recycling of non-metallic fractions from waste printed circuit boards: a review," Journal of Hazardous materials, vol. 168, no. 2-3, pp. 567-590, 2009.

[6] Y. J. Park and D. J. Fray, "Recovery of high purity precious metals from printed circuit boards," Journal of Hazardous materials, vol. 164, no. 2-3, pp. 1152-1158, 2009.

[7] Z.-F. Cao, H. Zhong, G.-Y. Liu, and S.-J. Zhao, "Techniques of Copper recovery from Mexican copper oxide ore," Mining Science and Technology, vol. 19, no. 1, pp. 45-48, 2009.

[8] B. Bayat and B. Sari, "Comparative evaluation of microbial and chemical leaching processes for heavy metal removal from dewatered metal plating sludge," Journal of Hazardous materials, vol. 174, no. 1-3, pp. 763-769, 2010.

[9] H. Z. Mousavi, A. Hosseynifar, V. Jahed, and S. A. M. Dehghani, "Removal of lead from aqueous solution using waste tire rubber ash as an adsorbent," Brazilian Journal of Chemical Engineering, vol. 27, no. 1, pp. 79-87, 2010.

[10] M. Yilmaz, T. Tay, M. Kivanc, and H. Turk, "Removal of corper(II) ions from aqueous solution by a lactic acid bacterium," Brazilian Journal of Chemical Engineering, vol. 27, no. 2, pp. 309-314, 2010.

[11] J. L. P. Sheeja and P. Selvapathy, "Comparative study on the removal efficiency of cadmium and lead using hydroxide and sulfide precipitation with the complexing agents," International Journal of Current Research in Chemistry and Pharmaceutical Sciences, vol. 1, no. 6, pp. 38-42, 2014.

[12] L. H. Yamane, V. T. de Moraes, D. C. R. Espinosa, and J. A. S. Tenório, "Recycling of WEEE: characterization of spent printed circuit boards from mobile phones and computers," Waste Management, vol. 31, no. 12, pp. 2553-2558, 2011.

[13] M. Delfini, M. Ferrini, A. Manni, P. Massacci, L. Piga, and A. Scoppettuolo, "Optimization of precious metal recovery from waste electrical and electronic equipment boards," Journal of Environmental Protection, vol. 2, no. 6, pp. 675-682, 2011.

[14] D. Pant, D. Joshi, M. K. Upreti, and R. K. Kotnala, "Chemical and biological extraction of metals present in E-waste: a hybrid technology," Waste Management, vol. 32, no. 5, pp. 979-990, 2012.

[15] E. Nishikawa, A. F. A. Neto, and M. G. A. Vieira, "Equilibrium and thermodynamic studies of zinc adsorption on expanded vermiculite," Adsorption Science and Technology, vol. 30, no. 8-9, pp. 759-772, 2012.

[16] J. Sohaili, S. K. Muniyandi, and S. S. Mohamad, "A review on printed circuit boards waste recycling technologies and reuse of recovered nonmetallic materials," International Journal of Scientific and Engineering Research, vol. 3, no. 2, pp. 138-144, 2012.

[17] B. Ali, M. M. Salarirad, and F. Veglio, "Process development for recovery of copper and precious metals from waste printed circuits board with emphasize on palladium and gold leaching and precipitation," Waste Management, vol. 33, no. 11, pp. 2354-2363, 2013.

[18] B. Oleksiak, G. Siwiec, and A. B. Grzechnik, "Recovery of precious metals from waste materials by the method of flotation process," Metalurgija, vol. 52, no. 1, pp. 107-110, 2013.

[19] A. Vidyadhar and A. Das, "Enrichment implication of froth flotation kinetics in the separation and recovery of metal values from printed circuit boards," Separation and Purification Technology, vol. 118, pp. 305-312, 2013.

[20] S. Fogarasi, F. Imre-Lucaci, A. Imre-Lucaci, and I. Petru, "Copper recovery and gold enrichment from waste printed circuit boards by mediated electrochemical oxidation," Waste Management, vol. 273, pp. 215-221, 2014.

[21] U. Jadhav and H. Hocheng, "Hydrometallurgical recovery of metals from large printed circuit board pieces," Scientific Reports, vol. 5, no. 1, article 14574, 2015.

[22] J. Sheeja, "Studies on the removal of chromium with the complexing agents," Oriental Journal of Chemistry, vol. 32, no. 4, pp. 2209-2213, 2016. 

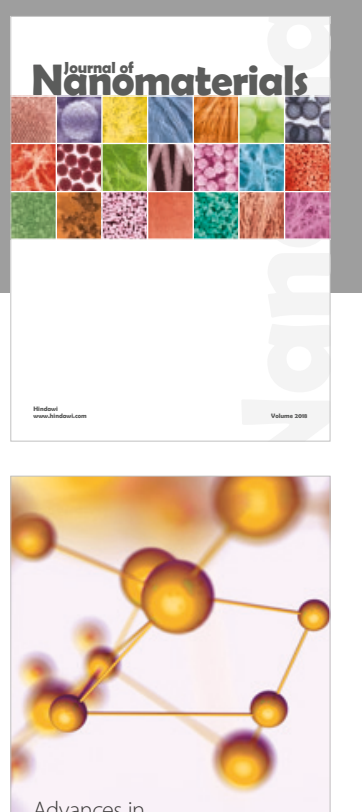

Physical Chemistry
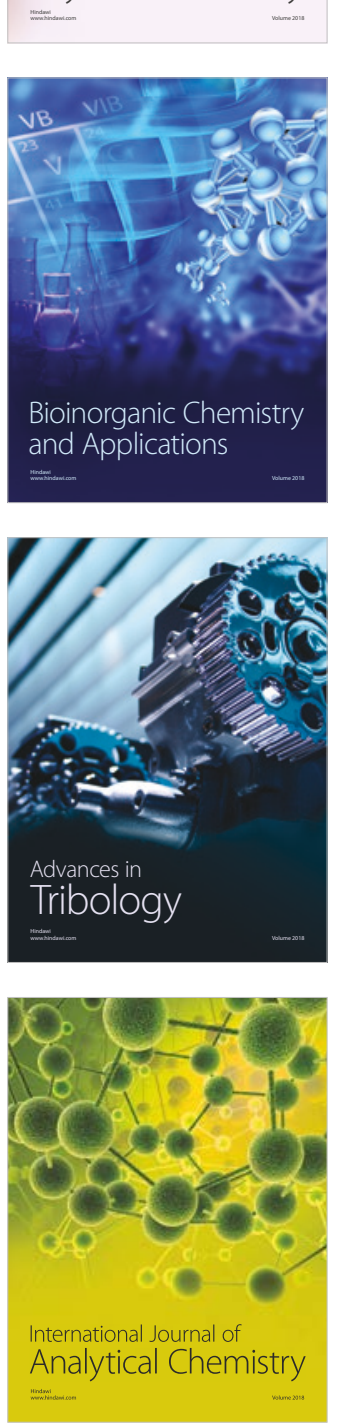

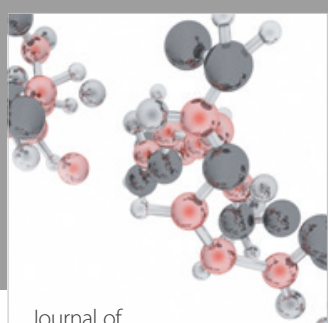

Analytical Methods

in Chemistry

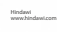

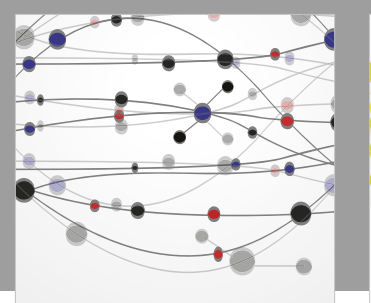

The Scientific World Journal

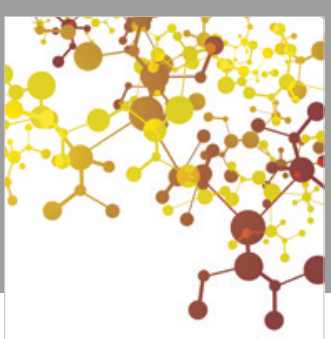

Journal of

Applied Chemistry
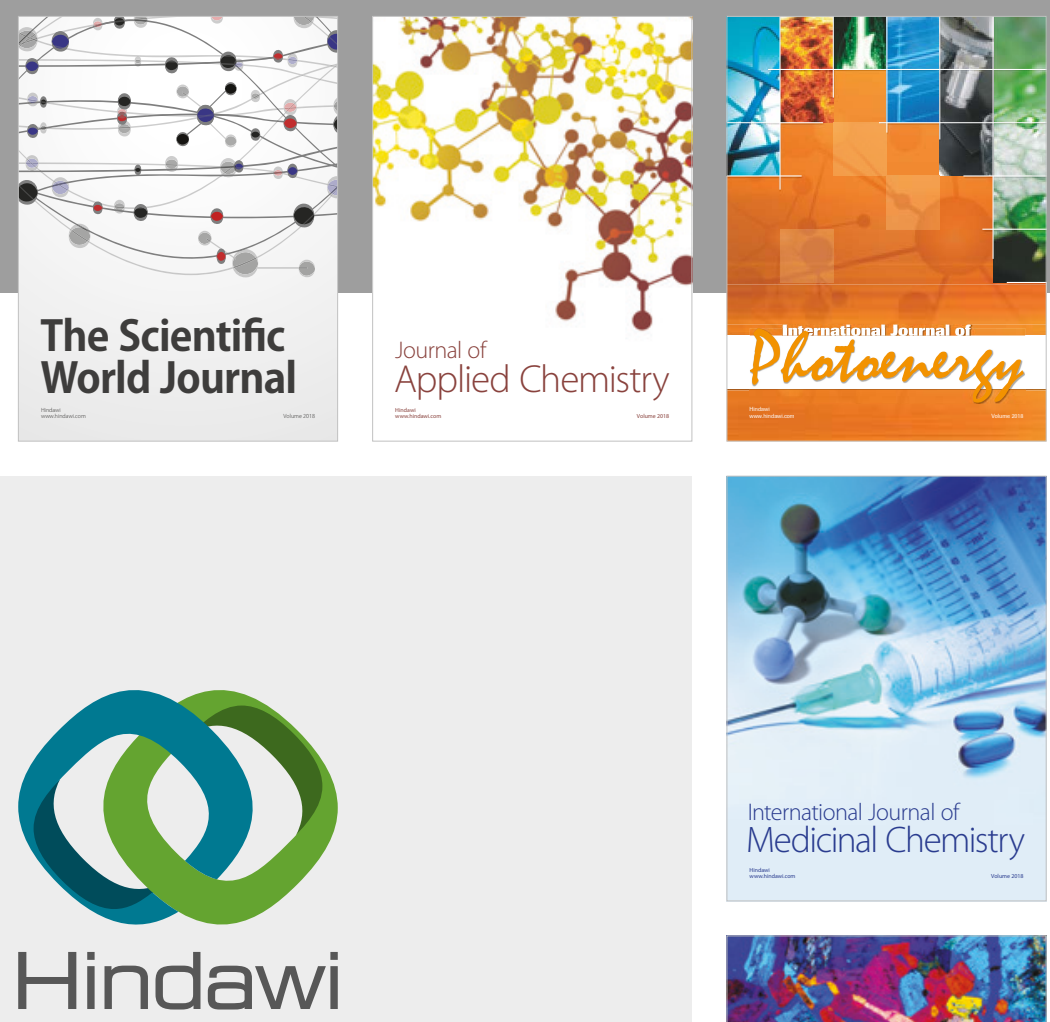

Submit your manuscripts at

www.hindawi.com
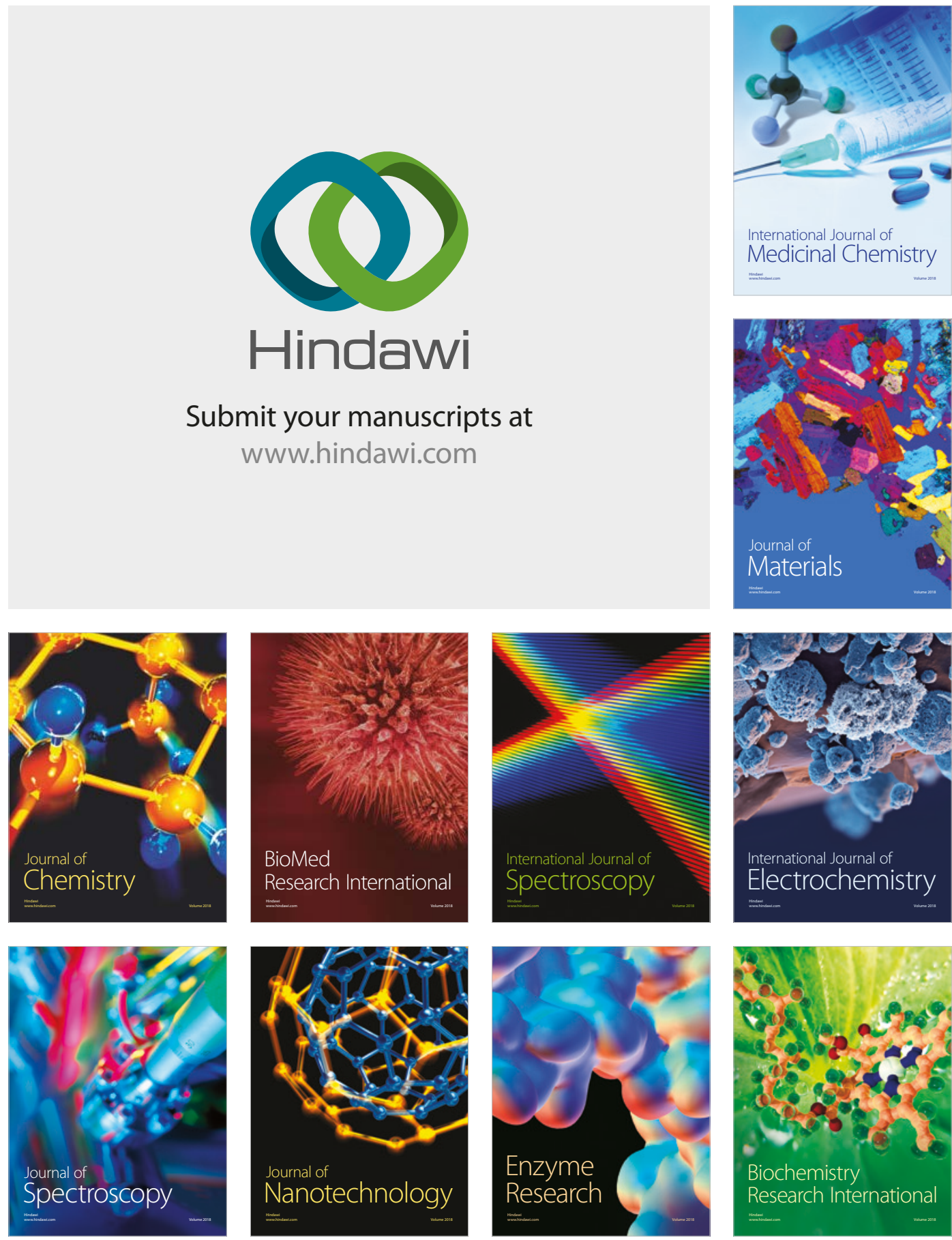
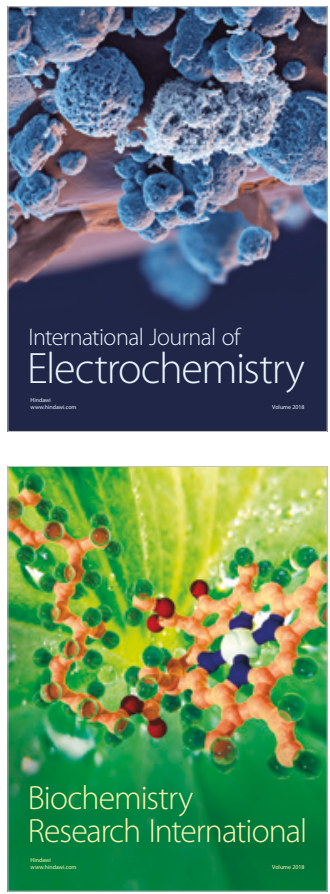